\title{
Music Composition of Accompaniment for Fusion Dance 8 Ethnics of North Sumatera
}

\author{
Theodora Sinaga \\ Lecturer of Music Education Study Program at State University of Medan, Indonesia \\ b4khrul.4m4l@gmail.com
}

\begin{abstract}
This study aims to examine the process of creating musical accompaniment to dance composition and the function of music in a composition of dance works. This study is conducted by using qualitative descriptive method and systematic data analysis by using the concept of dance music creation theory to deepen and interpret data specifically, the answer are found that the process of creating a composition of dance accompaniment music with the theme of a combination of eight North Sumatra ethnic groups are as follows; 1) The creation process of the dance music is a process that involves intensely between dance stylists and dancers with music stylists along with music players, in adjusting between the gestures of the dancers and the form of music as a dance accompaniment. 2) Some important things done by the music stylist (composer) in the process of composing dance accompaniment music include; a) Conduct pre-composition, b) Perform initial composition, 3) Revise composition, 3) Perform final composition. 3) The function of music in dance works includes; a) Music functions in asserting movements in dance. b) Music functions as a marker in changing dance movements, c) Music functions as a marker of atmosphere in dance. d) Music functions to strengthen the emotions of dancer. e) Music functions to strengthen the picture of the atmosphere in parts of dance composition. $f$ ) Music functions to regulate the tempo, rhythm and dynamics of dance movements. $g$ ) Music functions to emphasize the accentuations of dance movements. h) Music functions as an introduction to the climax of dance work.
\end{abstract}

Keywords : Music Composition, Music Function, Fusion Dance

\section{Introduction}

A dance work does not merely rely on gestures as a medium, but also requires other artistic elements which are an important part of a dance performance. The accompaniment of dance music, costumes, or other properties in supporting the beauty of a dance performance becomes one unit that helps build the astetic value of a dance performance. In connection with this, a composition of music as a accompaniment of dance works requires a solitary collaboration between music artists and dance artists, this is something that is very common to do. In the context of the performance of dance works accompanied by musical composition, the combination of the two branches of art is a demand for the realization of better aesthetic values, including a combination of dance with other art disciplines in terms of completeness of property and stage setting.

In the author's observation of colossal performances of dance works, there was a very intense involvement between dance groups and musician groups. In this case the researcher tries to investigate the process of cooperation that occurs and the process of creating musical compositions to complement a dance composition performance. Based on the observations of the authors there are two groups of art disciplines that are seriously involved in this, namely the group of dancers and dancers and music arrangers and musicians. The group of music stylists involved is one of the music groups that concentrates on the traditional music genre of North Sumatra. However, they are very open to collaborating with other artists both dance, theater and other artists. The existence of a group of musicians who are always passionate and have many orders of musical compositions from various other art communities, becomes a 
focus of observation in this study. How this group proceeded to work on the composition of music for dance accompaniment colossally, and how this musical composition functioned in a dance work became the subject matter of this study.

In a dance performance in Medan, which is held every year, it always carries various themes of social life and also the themes of local life. On this occasion a group of young artists composed accompaniment music that carries the theme: "a combination of eight ethnic North Sumatra", the seriousness of this group ultimately resulted in a musical composition that can be said to be good and meet the satisfaction of both dance groups who use their services and their audience. How is their work process so that they are able to produce a good musical composition and how the function of music in the dance work becomes an interesting thing to study

\section{Research Methods}

This study is descriptive qualitative, namely the steps of conducting field observations, interviews, lab work, and analyzing data. Data analysis techniques are carried out by the process of analyzing and systematically compiling data obtained from interviews, field observations, and work results of the Lab, then selecting data and then organizing data into categories, describing into units, synthesizing, arranging into patterns, choose which ones are important, and will be studied, and make conclusions so that they are easily understood by themselves and others.

\section{Discussion}

\subsection{The process of Creating Cusical Compositions for Dance Accompaniment.}

The process of creating artworks basically comes from experience through ideas and ideas embodied in artistic expression, both in the form of dance and other music and arts. In the process of art, artists tend to consider things that can determine the quality or quality of their artwork. Some important things to note are the power of the artist's ability to manage these artistic elements, both technical and non-technical issues, such as composition issues, instrument use, playing techniques, the level of difficulty and refinement of art that can boost the aesthetic value of an artwork. This concept of creativity will give birth to a variety of highvalue works of art.

At the next stage of development, the combination of music and dance as part of performance art, is something that usually happens, where music acts as one of the elements that can make a dance performance more interesting and vice versa. Music composition that is intended as a dance accompaniment, basically can be created in various ways, ranging from the use of instruments, techniques to play it and how to compose it. In this case music as accompaniment in a dance composition or helping to strengthen expression (inspiration) in a dance work, does not mean that its existence is not important or is merely a supporter of dance work.

The combination of accompaniment music with dance is a unified whole and in the end will have an impact on the performance. Music and dance in this case work together in creating emotional touches to the dancers and viewers. The combination of the composition of music with dance is always related to the mechanism in which there is an atmosphere effect in building dance movements. The combination of accompaniment music with dance covers the 
area of quality of space and time, what dancers will do in performing dance movements and the composition of music as a dance accompaniment can be done optimally. Therefore, in combining music with a dance, it is necessary to have intense cooperation in order to create a harmony between music and dance.

\section{- The Form of dance composition}

This dance work was created based on eight ethnic North Sumatra dance movements, by exploring the eight main ethnic movements in North Sumatra. namely: Malay dance traditions, Toba dance traditions, Mandailing dance traditions, Angkola dance traditions, Simalungun dance traditions, Dairi dance traditions, Nias dance traditions, coastal dance ethnic. This dance work is divided into 3 main parts, namely: 1 opening part, 2) the contents of the dance piece, 3 ) the closing section. In the content section of the dance consists of four main parts by being coded starting from part A, part B, part C, and part D. Each main part with the material of motion and setting the atmosphere differently. The following is a complete form of dance composition:

1. The opening part (dance introduction).

2. Section contents:

- Composition of dance form A (Karo ethnic and Pak-Pak ethnic movement material, village atmosphere in the morning)

- Composition of dance form B (ethnic movement material of Malays and Ethnic Toba, atmosphere of activity of doing fun between men and women)

- Composition of dance form C (Material of ethnic Mandailing and Ethnic Simalungun movement, atmosphere of giving advice in living life)

- The composition of dance form D (seal of movement of the coast and ethnic Nias, atmosphere, disputes between youth and ended a happy peace)

3. The closing section

- Showing cross-cultural in social dynamics manifested in the combination of the movements of eight ethnic North Sumatra.

In this case if the aspect of dance movement has its roots in certain ethnic dances, then the accompaniment music must depart from the traditional music in question. This is considered important to present a regional atmosphere of ethnic - ethnic diversity in North Sumatra. Because the dance works departed from the framework of the eight ethnic North Sumatra concept, the composer made a musical composition rooted in eight ethnic North Sumatra. This includes Malay ethnicity, Toba Batak ethnicity, Karo ethnicity, Simalungun ethnicity, Mandailing ethnicity, Angkola ethnicity, Pakpak-Dairi ethnicity, Nias ethnicity, and Pesisir sibolga as the source of the creation of dance accompaniment.

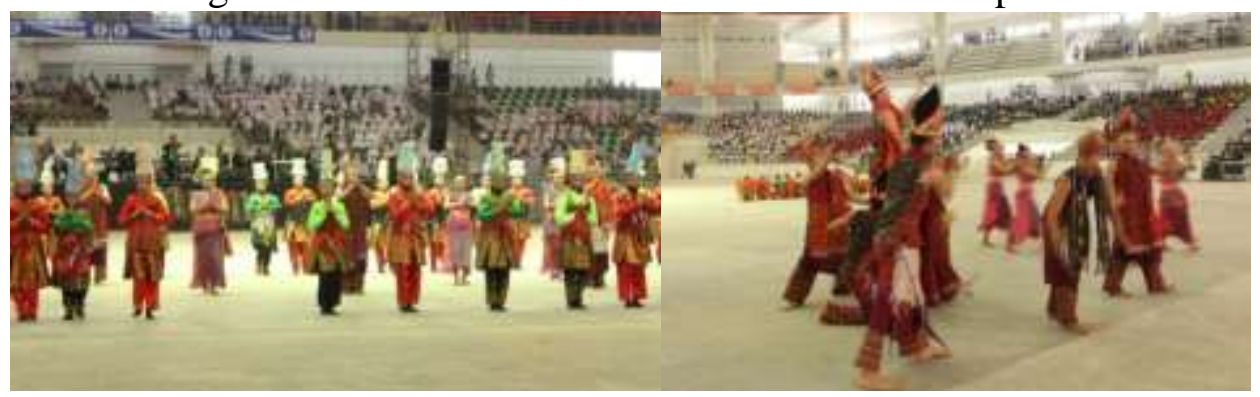

Figure 1. Performances of eight ethnic North Sumatra based dance works 


\section{- The process of creating musical composition of accompaniment dance}

Several phases carried out in the process of cooperation in the cultivation of the composition of dance accompaniment music:

1. Pre-composition phase

In the pre-composition phase is preparation in working on the composition of dance accompaniment music by doing several things, including:

a. Conduct discussions and equation about matters relating to dance works (various forms of motion in dance, the atmosphere in each part, tempo, rhythm, and other aesthetic elements).

b. Observe various aspects of dance, atmosphere, rhythm and tempo of dance.

c. Designing musical compositions for the results of discussions and observations made.

d. Preparing sound material.

e. Prepare music players and musical instruments to be used.

f. Arrange training schedule

2. Initial composition phase

In the initial composition phase several things are carried out, including:

a. Arranging the composition of dance accompaniment compositions based on the form of complex dance works.

b. Compose sound material by writing models of rhythm, rhythm, melody and accompaniment chords on each part of the dance work.

c. Playing the composition of early music with the music players

d. Application of initial compositions to dance works through joint training

e. Equation of effects and various responses to the application of early musical compositions.

3. Phase composition revision

In the revision phase several things were carried out, including:

a. Perform joint corrections to the composition of the initial music

b. Revise both addition and subtraction of various musical aspects to the composition of the initial music.

c. Re-applying the revised music to dance works can find maximum results

4. Final composition phase

This phase is the composition of dance accompaniment music that has no longer undergone changes and is ready to be played in accompanying dance works.

In collecting musical sound idioms as material for the composition of dance accompaniment, tracking of melodic, rhythmic and rhythmic forms on the ethnic music culture in North Sumatra is carried out. The following is a table of sources for musical idioms used in the composition of the accompaniment of eight ethnic North Sumatra folk dance accompaniment.

Table 1. Source of Musical Idioms

\begin{tabular}{|l|l|l|}
\hline No & Source of musical idioms & $\begin{array}{l}\text { Originally a source of musical } \\
\text { idioms }\end{array}$ \\
\hline 1 & $\begin{array}{l}\text { - Simalungun rayat } \\
\text { - oda-oda } \\
\text { - patam-patam }\end{array}$ & Karo \\
\hline
\end{tabular}




\begin{tabular}{|l|l|l|}
\hline 2 & - gondang hucapi & Pakpak \\
\hline 3 & $\begin{array}{l}\text { Ritem irama gendang Melayu } \\
\text { - Senadung } \\
\text { - Joget } \\
- \text { Zapin }\end{array}$ & Melayu \\
\hline 4 & - Ritem gondang tor-tor & Batak Toba \\
\hline 5 & $\begin{array}{l}\text { - Gondang bulu } \\
\text { - Onang-onang }\end{array}$ & Mandailing \\
\hline 6 & - gondang & Simalungun \\
\hline 7 & - ritem tari pergaulan & Nias \\
\hline 8 & - Senandung pesisir sibolga & Pesisir sibolga \\
\hline
\end{tabular}

- The Footage of the Early Part of the Composition of Dance Accompaniment Music

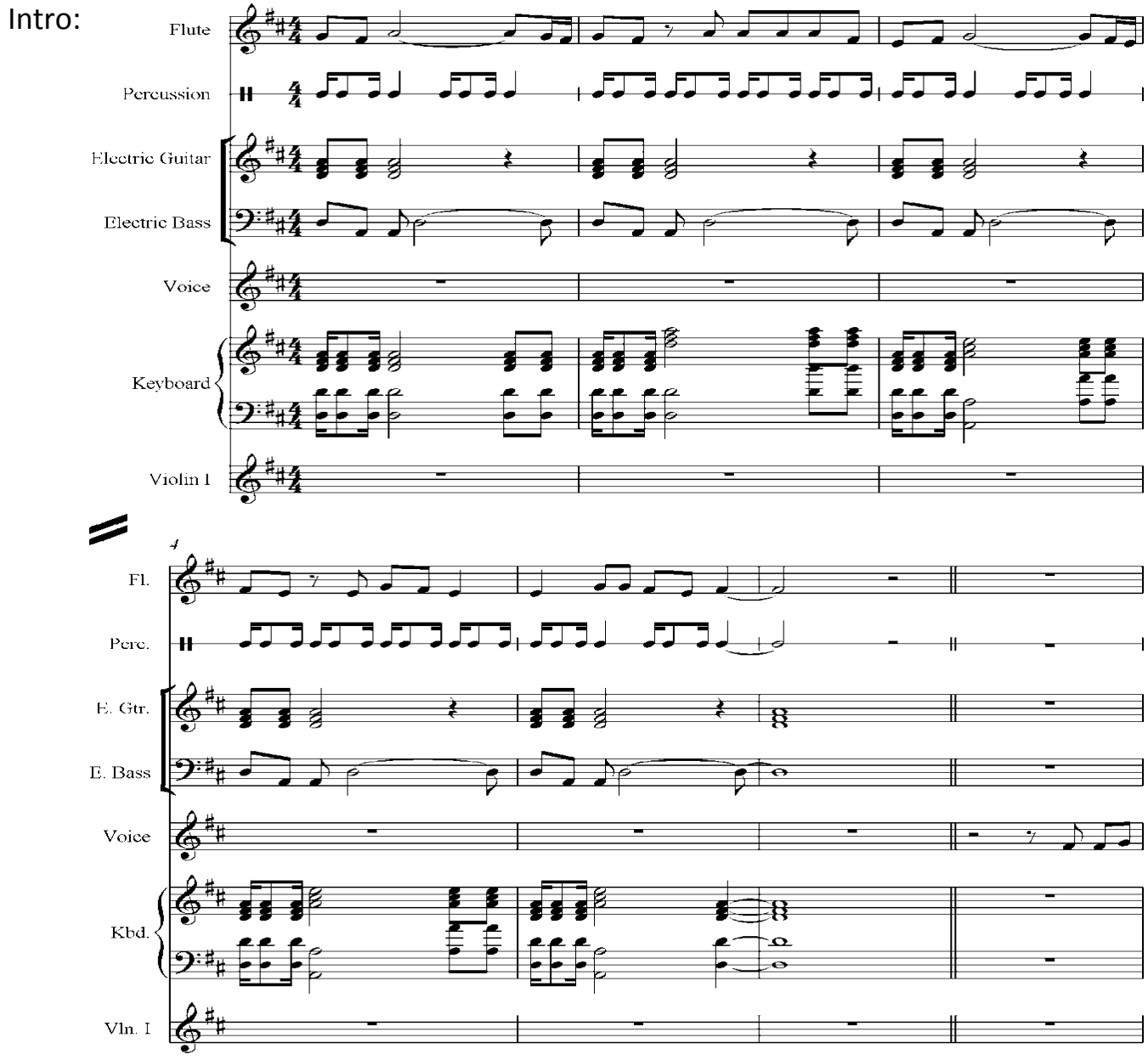

\subsection{Music Function in Performing dance works}

In this case music as one type of art that has a role towards other types of art (dance composition) becomes one interrelated entity. In this connection, the relationship between music and dance cannot be separated in a performance package, because music has a very 
important role and contribution in this connection. This can be proven by several musical functions in a dance work, including:

1. Music functions in asserting movements in dance.

2. Music functions as a marker in changing dance movements

3. Music serves as a marker of the atmosphere in dance.

4. Music functions to strengthen the emotions of dancer.

5. Music serves to strengthen the picture of the atmosphere in parts of dance composition.

6. Music functions to regulate the tempo, rhythm and dynamics of dance movements.

7. Music functions to emphasize the accentuations of dance movements

8. Music serves as an introduction to the climax of dance work.

Thus the results of intense cooperation between dance stylists and dancers and musicians together with the music players is not a job that can be considered crumb, because it requires a serious and very long collaboration. It also involves various disciplines of artistic elements that exist. From starting to compose techniques, choosing music players, techniques to make music instruments, choosing musical idioms and other things that surround this activity are very complex. However, the results of the hard work that has been done by the parties concerned have produced a good performing art that can be enjoyed by art lovers and provides its own aesthetic experience for the actors and connoisseurs.

\section{Conclusion}

Based on the study conducted, it can be concluded that the process of creating a composition of dance accompaniment music with the theme of the combination of eight ethnic North Sumatra is as follows;

1. The process of creating music in dance works is a process that involves intensely between dance stylists and dancers with music stylists along with music players in adjusting between the movements of the dancers and the form of music as a dance accompaniment.

2. Some important things done by the music stylist (composer) in the process of composing dance accompaniment music include;
a. Pre-composition
b. Perform initial composition
c. Perform composition revisions
d. Perform final composition.

3. The function of music in dance activities includes;

a. Music functions in asserting movements in dance.

b. Music functions as a marker in changing dance movements

c. Music serves as a marker of the atmosphere in dance.

d. Music functions to strengthen the emotions of dancer.

e. Music serves to strengthen the picture of the atmosphere in parts of dance composition.

f. Music functions to regulate the tempo, rhythm and dynamics of dance movements.

g. Music functions to emphasize the accentuations of dance movements

h. Music serves as an introduction to the climax of dance work. 


\section{References}

Cholid, Naburko. 2005. Metodologi Penelitian. Jakarta : Bumi Aksara.

Dharsono, Sony Kartika, 2004. Memahami Seni dan Estetika. Bandung: Rekayasa Sains.

Merriam, Alan P. 1964. The Anthropology of Music. Evaston Ill: Northwestern University Press.

Maleong, J Lexy. 2000. Metodologi Penelitian Kualitatif. Bandung : Remaja Rosdakarya.

Miles, B. Matthew dan Huberman., A.Michael. 1992. Analisis Data Kualitatif. Jakarta : UIPRESS. Media.

Murgiyanto, Sal, 1996. "Cakrawala Pertunjukan Budaya: Mengkaji Batas dan Arti Pertunjukan." dalam Jurnal Seni Pertunjukan Indonesia th. VII. Yogyakarta: MSPI dan Yayasan Benteng Budaya.

Pusat Pembinaan Bahasa 2010. Kamus Besar Bahasa Indonesia. Jakarta : Balai Pustaka.

Suroso Panji. 2012 Ketoprak Dor Di Helvetia, unimed perss.

Syani, Abdul. 1994. Skematika Teori dan Terapan. Jakarta: Bumi Akasara.

Tambajong, Japi. 1992. Ensiklopedi Musik Jilid 1. Jakarta : Cipta Adi Pustaka. 